Gall-fly.-With the exception of a little rufous on the joints of the feet and on the base of the mandibles, the colour is deep black. Head finely rugose, face with two parallel grooves and median ridge, antenure I4-jointed, 3 rd joint as long as 1 st and 2 nd or 4 th and $5^{\text {th }}$ united ; ocelli well separated and inconspicurous. Thorax glabrous above, parapsidal grooves very distinct and extending to the collar, scutellum rugose, with basal groove, mesopleuræ smooth and glabrous beneath the wings. Abdomen shining, black, without sculpturing, the posterior margin of the and segment quite oblique. Wings long, hyaline, beautifully iridescent, nervures slender. Feet black, tibiæ set with a very fine gray pile. Length, $21 / 2 \mathrm{~mm}$. Wings, $4 \mathrm{~mm}$.

Described from one bred female.

(To be continued.)

\title{
CORRESPONDENCE.
}

LITHOPHANE ORIUNDA.

Sir,-Two localities may be mentioned additional to those given by Mr. Moffat in July (1893) number.

Mr. Grote has recorded Wisconsin as a habitat of Oriunda, and I can say that a single specimen was collected at Galena, Illinois, Sept. 26, $\mathrm{r} 875$, from a sugared tree.

Thomas E. Bean, Laggan, Alberta.

Sir,-I wish, on behalf of the Entomological Society of Ontario, to acknowlede the receipt of a contribution to the Society's collection of native Coleoptera, from Mr. A. H. Kilman, of Ridgeway. It consists of over a hundred and fifty species that were wanting in the Society's cabinets, all nicely mounted and in fine condition.

London, May i6th, 1894.

J. Alston Moffat, Curator.

IS CENONYMPHA TYPHON SYNONYMOUS WITH C. INORNATA?

Sir,-Will American entomologists who are acquainted with the European forms of Cononympha typhon, especially with vars. laidion, Bork, and isis, Tett (probably identical), inform me whether Cononympha inornata, Edw., is a distinct species or is identical with these varieties? From the descriptions, I incline to the latter view, but an inspection of some specimens of the American insect in the British Museum (Natural History), not very first-rate ones by the way, rather lends countenance to the former.

London N, England.

F. I. Buckell, M. B., 32 Canonbury Square. 
GLASS TUBES AS INCUBATORS.

Sir,-On June the $24^{\text {th, }} 1893$, I was obliged to go to my home in the High Sierras and beyond the Yosemite $22 \mathrm{I} / 2 \mathrm{miles}$, as I had some moth eggs that $I$ wanted to hatch and rear larvæ from. Before going I placed all the leaves that had eggs on them in a small glass jelly jar; being three days getting there, on account of the deep snow, I kept putting in fresh leaves every day for the young larvæ to feed on, as the eggs had begun to hatch before I started, and when I got home I had more dried and withered leaves than I bargained for, and in consequence lost some of the smaller larvæ that had hidden themselves. To prevent a recurrence of such loss, I thought of some glass tubes that were sent to me by Prof. Riley. I then separated all the leaves that had eggs on them, cut away all the superfluous dry parts of the leaf, and placed them all in one of these tubes, introducing a fresh leaf or part of one until a newly hatched larva made its appearance; I would then draw him out with the leaf and place him in another tube, or on a potted plant, thus ensuring correct data and better chances of observing its natural life-habits. This also ensures saftey to both eggs and the young larve, as new food can be introduced and the old extracted without annoying the larvæ.

John B. Lembert, Yosemite, Cal.

THE ASSOCIATION OF ECONOMIC ENTOMOLOGISTS.

The Association of Economic Entomologists will hold its annual meeting this year in Brooklyn, N. Y., August $4_{4}$ th and $5_{5}$ th, dates immediately preceding the meeting of the American Association for the Advancement of Science.

The fact that the meeting is to be held in Brooklyn is a sufficient guarantee of a large attendance and a meeting of more than usual interest. It is sincerely hoped that every member who can will be present, with papers to read, questions to ask and ideas to impart, that will make the meeting profitable and send all back to their posts of duty inspired to better work. C. P. Gillette, Sec'y., Fort Collins, Colo. 


\section{ASSEMBLING OF ATTACUS PROMETHEA.}

Sir,-About 3 o'clock p.m., on the I Ith of June, whilst hunting along the east side of a high picket fence, running north and south, with woods on the west, and a field on the east, my attention was arrested by the unusual movements of what $I$ thought was a black butterfly. It was fluttering up and down the tall pickets, passing through between them and returning again, in a state of evident excitement. It left off, and flew close by me, when I saw that it was a male promethea. Meanwhile another had taken its place, and was going through similar movements. $I$ at once inferred that a female must be in that vicinity. I moved onward, looking between the pickets, and I saw a female suspended to the lower end of a cocoon, out of which she had probably emerged that day. The cocoon was attached to the end of a slender twig, I 2 or 14 inches from the fence, and about 4 feet from the ground.

I remained close by and watched the movements. There were at least four males on the wing. They would fly 20 or 30 feet along the fence, either way, and return. They never flew far afield, and I did not see that they ever entered the woods, whilst one or other of them was always fluttering about the spot, regardless of my presence. They seemed to tire themselves out in a main effort to locate the object of their search. I had watched for about fifteen minutes, when one came quietly along, passed between the pickets, fluttered hither and thither for an instant, then I saw its mate was found. During my observation the female was perfectly quiescent; not a movement of wing or foot. There were three males still on the wing when I left.

Are we to consider $A$. promethea a day flyer? or are all the Suturniida ready to pair at any hour of the twenty-four when circumstances are favourable? It seems they do not require to fly at all to feed. The female may oviposit during the night.

I was greatly impressed during the observation by noticing how little, if at all, eye-sight was made use of.

J. Alston Moffat.

Mailed August Ist, 